https://doi.org/10.15407/socium2020.01.108

UDC 331.5.024.5 + 339.97+364.23

JEL E26, J24

Blyzniuk V.V., PhD. in Economics, Head of the Department of Socio-Economic Problems of Labor, SO "Institute for Economics and Forecasting, National Academy of Sciences of Ukraine", 26, Panasa Myrnoho Str., Kyiv,01011, Ukraine, email:vikosa72@gmail.com

\title{
INFORMAL EMPLOYMENT: RISKS AND CONSEQUENCES FOR THE UKRAINIAN LABOR MARKET
}

Institutional pathologies and the inability of the institutional order of the labor market to adapt to possible changes is manifested in the expansion of the informal segment of labor market and in the distortionof social and labor relations. The author considers theoretical approaches to defining the volume and characteristics of the informal segment of the labor market. Generalized are the advantages and disadvantages of individual methods of estimating informal employment. Using logistic regression, author evaluates the risks of informal employment by socio-demographic characteristics, employment levels and occupation. According to the results of the evaluation, it is proven that the most dangerous age is the youngest and the oldest age groups, as these categories are the most vulnerable and socially unprotected in market conditions. It is those lacking vocational education who have the greatest risk of entering the informal employment segment. The calculations prove that having a vocational education significantly raises the "gain" for women employed in agriculture, and information and telecommunications. It is proven that the structure and level of employment in the formal and informal sectors is an important factor in aggregate labor productivity. By evaluating the aggregate productivity of formal and informal market segments, the author substantiates the importance of the relocation component in terms of economic development prospects. Thus, the calculations prove that the effect of the flow of workers between the informal and formal segments is quite significant for agriculture, trade and construction. While, on the contrary in healthcare, education, transport, and processing, the impact of the intra-industry component on aggregate productivity is greater in comparison to the displacement factor. The weight of the relocation component in the economy as a whole is higher than that of the intra-industry impact factors. Creating an institutional environment that would help reduce the economic activities in the informal segment would objectively promote economic growth.

Keywords: labor market, employment, informal employment, aggregate labor productivity, risk of informal employment, logistic regression.

Близнюк В.В., канд. екон. наук, завідувач відділу сочіально-економічних проблем праці ДУ "Інститут економіки та прогнозування НАН Украӥни", вул. Панаса Мирного, 26, Київ, 01011, Україна, email: vikosa72@gmail.com

\section{НЕФОРМАЛЬНАЯ ЗАЙНЯТІСТЬ: РИЗИКИ ТА НАСЛІДКИ ДЛЯ УКРАЇНСЬКОГО РИНКУ ПРАЦІ}

Інституціийні патології та нездатність інституційного порядку ринку праці адаптуватися до можливих змін проявляється у поширенні неформального сегмента ринку праці та деформалізачії сочіально-трудових відносин. Розглянуто теоретичні підходи до визначення обсягів $i$ характеристик неформального сегмента ринку праці. Узагальнено переваги та недоліки

(C) Blyzniuk V.V., 2020 


\begin{abstract}
окремих методів оцінки обсягів неформальної зайнятості. Використовуючи логістичну регресію, здійснено авторські оцінки ризику неформальної зайнятості за соиіальнодемографічними ознаками, рівнями зайнятості та професійно-галузевої приналежності. 3 а результатами оцінювання доведено, щзо особливо небезпечним віком $\epsilon$ наймолодша та найстарші вікові групи, оскільки саме иі категорії населення є найвразливішими та соиіально незахищеними в умовах ринку. Саме ті особи, які не мають професійної освіти, мають найвищий ризик потрапити до сегмента неформальної зайнятості. Розрахунки доводять, щэо наявність професійної освіти істотно збільшуе “виграш” для жінок, зайнятих у сільському господарстві, інформаџіï та телекомунікаџії. Доведено, щчо структура та рівень зайнятості у формальному та неформальних секторах економіки є важливим фактором агрегованої продуктивності праці. Очінивши агреговану продуктивність праці формального та неформального сегментів ринку, автори обтрунтовують важливість реалокаційної компоненти щзодо перспектив економічного розвитку. Так, розрахунки доводять, щчо ефект впливу переміщення прачівників між неформальним і формальним сегментами є достатньо вагомим для сільського господарства, торгівлі та будівництва, і навпаки у сфері охорони здоров'я, освіти, транспорту, переробної промисловості вплив внутрішньогалузевої компоненти на агреговану продуктивність праці є вагомішою порівняно з фактором перемішення. Вагомість реалокаційної компоненти у цілому в економіці є вищою, ніж внутрішньогалузевих факторів впливу. Формування інституиіійного середовища, щзо сприятиме зменшенню економічної активності неофіційного сегмента, об 'єктивно сприятиме економічному зростанню.
\end{abstract}

Ключові слова: ринок прачі, зайнятість, неформальна зайнятість, агрегована продуктивність праці, ризик неформальної зайнятості, логістична регресія.

The development of market relations in Ukraine is accompanied by significant changes in the sphere of labor and employment, and leads to the emergence of new regularities and features of the functioning of the labor market of both positive or negative nature. Among the current challenges in the field of socio-economic relations, a very important one is the deshadowing of the labor market. Urgency of the problem of the legalization of employment and wages today is due to its scale and extremely negative and devastating consequences. The inability of the institutional order of the labor market to adapt to possible changes will be manifested through the prism of anomie in the system of social and labor relations. Institutional pathologies or anomies are clearly manifested in the structure of economic mechanisms of the socio-economic sphere, which forms a shadow sector of the economy and distorts social and labor relations.

The problems of informal employment dissemination and the development of mechanisms that will help to minimize the negative consequences have been addressed in the work of numerous domestic researchers, such as E. Libanova [1], Yu. Kharazishvili [2], A. Kolot [3], T. Burlay [4], L. Shaulska, O. Grishnova [5], T. Zaiats, O. Kuznetsova, O. Novikova, S. Shumska, O. Nezhyvenko [6], O. Tsymbal [7] and others. Despite sufficient attention and theoretical elaboration of the problem, it still remains relevant and requires additional analysis and justification of effective instruments of state employment policy. The identification of the main informal employment determinants, the justification of the internal heterogeneity of this labor market segment and the quantitative assessment of risks for certain categories of employed population to be excluded from the formal sector, led to the suggested study. One of the tasks was to update the calculations and to confirm or refute the 
thesis that moving between sectors with different productivity levels would determine the prospects for economic development.

Considering these aspects, the purpose of the study is to assess the risk of labor relations deformation for certain socio-demographic categories of employed and to test the hypothesis of the impact of labor relocation between formal and informal segments on the aggregate labor productivity, which will allow substantiating state instruments of employment unshadowing.

The study of the phenomenon of deformalization of labor relations is quite complicated from the standpoint of uncertainty of definitions, methodological approaches to measuring and interpreting the consequences. According to K. Williams [8, p. 742], informal employment may result from the spread of social exclusivity in society among marginalized and discriminatory populations (labor migrants, youth, women, retirees) and voluntary withdrawal from formal market institutions of social and labor relations. The proliferation of informal institutions is a consequence of either the weakness of formal institutions, or the low level of awareness of labor relations, or the rigidity of labor law. Voluntary choice of informal or shadow labor relations is the object of behavioral economics studies, on whose foundations one can determine the influence of psychological factors on economic decisionmaking [9, p. 324].

The basis of labor statistics and employment measurement in the informal sector by international organizations was laid in the approach proposed by K. Hart [10], whose essence is this segment of the labor market is primarily filled with persons who are forced to perform primitive, unskilled, low-paid and socially unprotected work. This statistical approach was called productive, and was used not only to measure informality statistically, but also to serve as basis for political initiatives related to poverty in developing countries. Most often, such employment is identified with "bad" jobs with low wages, productivity and uncompetitive individual characteristics of employees [11].

Analyzing urban migration and the dynamics of expected wages in different segments of the labor market, and based on the theoretical foundations of the dual labor market, J. Harris and M. Todoro continued theoretical and practical studies of informal labor relations and the main determinants of their distribution [12]. This made it possible to revise the theory of the informal sector and to substantiate the conclusions about the significant impact of globalization, about the change in working conditions and educational level of the labor force due to the heterogeneity and segmentation of the labor market into formal and informal parts.

Improvement in the statistical accounting of informal employment has led to the formation of a more general - legalistic approach, which focuses on compliance with the state formal restrictions; informal employment in this case is not registered, not regulated and not protected by the state [13]. The validity of using this tool also has an error in evaluating the informal segment, since the problem of informal segment proliferation is explained not so much by cross-sectoral barriers as by the weak law enforcement as to the labor legislation, which is unable to ensure an even regulation regarding all corporate sector workers. 
Since informality was perceived by researchers as a sign of underdeveloped economic relations and the weakness of social institutions, the first surveys were performed on developing countries and on peripheral jobs in the secondary labor markets of developed countries [14], but it was later recognized that there were many types of employment in these countries that can be considered as informal [15-17]. In the transition economies, where the emergence of market relations is accompanied by socio-political changes, informality has a different nature. First of all, it may be caused by institutional changes, the latest adaptation mechanisms of labor market actors, and low levels of labor law enforcement. One of the characteristics of the atypical manifestation of the post-Soviet countries is the accumulation of wage arrears, the spread of forced underemployment, employment under civil agreements instead of full-fledged employment agreements [18], which led to the spread of informal employment among workers.

The above distortions of social-labor relations also show up in the formal sector. In both developing and post-Soviet countries, the most common form of informal employment is self-employment and free labor of family members, which is widespread in the background of a weak social protection system and is a temporary alternative to unemployment. Under certain conditions, and in the absence of a desire to register as a legal entity, this segment is the upper layer of informality [19], and when hired workers are employed in this segment for whom the employer does not want to pay social contributions, this is already a case of forced informality in the lower layer of the informal segment of labor market.

Recently, the revisionist approach has been gaining round whereby the principle of labor market duality is questioned and participation in informal employment is a voluntary choice and there are no barriers to the transition from the informal segment to the formal one. At the same time, supporters of this concept agree with the existence of differences in earnings in some of these segments.

The differences between the formal and informal segments are fairly conditional, with a significant number of jobs being hybrid, that is, formal by one trait and informal by the other. It is inherent, for the formal sector to create a large number of "bad" jobs, and, for the informal sector, to create jobs with high levels of remuneration and employment conditions, therefore, in the future the informal sector will be further segmented in terms of conditions and level of remuneration. In today's economies, formal and informal activities are not so much exclusionary as complementary to one another through the recycling of labor [20]. In contemporary research, such a broader view of informality is dominant, proving the lack of benefits of a particular form of functioning of the economy and social and labor relations.

Today, there is no region or country in the world, no matter what level of economic development they have reached, where informal employment has been overcome, which makes it possible to consider it as a certain new norm (a ubiquitous, established phenomenon) of today's global labor market. One of the main reasons for the transformation of informal employment into part of the "new normality" in global development is, according to experts, a new economic paradigm, that is, formation of a model of a hybrid economy that simultaneously includes the traditional and new non-standard types of employment, its formal and informal aspects, and its large and small scale [4;21]. 


\section{Blyzniuk V.V.}

Scientific literature has used various concepts to describe the informality of labor relations from informal and shadow employment to undeclared work [6; 7], and international statistical standards for evaluating the extent of this phenomenon have been combined in ILO approaches used since the 1990s [11]. Considering the advantages and disadvantages of various approaches [22] found in the scientific literature, alternative quantitative estimates of informal employment in Ukraine have been made based on the household micro-files on economic activity: mixed, quantitative, social and contractual methods [23]. Such calculations prove that the assessment methodology determines the statistical discrepancy between estimates of not only informal employment but also its socio-demographic profile. Based on the quantitative estimates, it is concluded that the most comprehensive and comparable to the quantitative estimates of the State Statistics Committee of Ukraine is the mixed method [24] according to which informally employed persons are employed at enterprises that do not have the status of a legal entity, under the oral agreement and under civil contracts both in the formal and informal sectors.

Obtained by the mixed method of an array of socio-demographic characteristics of informally employed, author estimates the probability of being in a state of informality. Evaluation of risky events in the labor market is implemented in the work of many researchers using probabilistic models [25-28]. Estimating the risk of informality by using the binary logistic regression method using SPSS and MS Excel programs makes it possible to obtain the probability of this case while using binary variables (in this case, the occurrence or non-occurrence of a particular event). The obtained results will allow the development and substantiation of effective instruments of the state employment policy for minimizing the consequences of deformation of the labor market and labor relations. For the calculation, the primary micro file data of the Household Survey on Economic Activity 2018 was used. The resulting model trait - informal employment - changes on a dichotomous scale, and the factor traits on the metric and other scales. Using the maximum likelihood method in the SPSS statistical package, the degree of likelihood of being an informally employed person with a specific set of characteristics was estimated [29]. The data received from 116.9 thousand people with socio-demographic characteristics (gender, age, educational level, marital status, etc.) was used for the analysis.

The implemented method of estimation of logistic regression parameters - maximum likelihood method - allows to estimate the probability of an event occurrence (to be informally occupied) and to give qualitative characteristics of the model. We chose the forced method of introducing predictors into the model - the Enter method, when all the variables are simultaneously entered into the model and with the R2 Nagelkerke and R2 Cox $\&$ Snell estimates, which characterize the proportion of the impact of all model predictors on the variance of the dependent variable (see Table 1).

Table 1

Statistical characteristics of model quality

\begin{tabular}{|c|c|c|}
\hline-2 Loglikelihood & $R^{2}$ Cox\&Snell & $R^{2}$ Nagelkerke \\
\hline 21,456 & 0,478 & 0,813 \\
\hline
\end{tabular}

Source: model calculation data. 
In Alisson P. [30], the advantages of different methods of calculating R2 for logistic regression are discussed in detail. It is noted that SPSS uses R2 Cox \& Snell for binary logistic regression and R2 McFadden in assessing the adequacy of the polynomial model. The value of -2Log likelihood indicates that the model is adequate, other indicators are stable according to the results of the reconciliation statistics used in the logistic regression. Estimation of model fit to actual data was performed using the Hosmer-Lemeshow criterion (see Table 2), significance test - Chi-square criterion, ie, with the significance of $\mathrm{p}<0.05$, the hypothesis about the model's insignificance was rejected.

Table 2

Criterion of Hosmer-Lemeshow

\begin{tabular}{|c|c|c|}
\hline Chi-square & Degrees of freedom (df) & Significance (Sig.) \\
\hline 9,334705 & 8 & 0,003 \\
\hline
\end{tabular}

Source: model calculation data.

Since in our case, the p-level of the hypothesis was below 5 percent, and the value of Chi-square statistics allows us to state the high level of consistency of the model. We can conclude that the quality of the model is sufficient. Table 3 demonstrates the classification results of the simulation. Sufficiently high figures were obtained, ie $86.6 \%$ of cases were classified correctly.

Table 3

Model classification results

\begin{tabular}{|l|c|c|c|}
\hline \multirow{2}{*}{ Observed } & \multicolumn{2}{|c|}{ Predicted } & \multirow{2}{*}{$\begin{array}{c}\text { Percentage } \\
\text { Correct }\end{array}$} \\
\cline { 2 - 3 } & \multicolumn{2}{|c|}{ Informal employment } & 97,4 \\
\cline { 2 - 3 } & informal_employment & formal_employment & 36,3 \\
\hline Informal_employment & 10279 & 271 & 86,6 \\
\hline Formal employment & 1455 & 830 & \\
\hline Total, \% & \multicolumn{2}{|c}{} \\
\hline
\end{tabular}

Source: model calculation data.

The following Table 4 lists the logistic regression variables.

According to the results presented in Table 4 and according to Wald test statistics, the most significant factors for informal employment are lack of vocational education, employment in agriculture, increase of the age of the employed population. The Wald test allows you to evaluate the validity of this model, its advantages is that the confidence interval of this test is a closed form. The significance of the factors is also confirmed by the corresponding p-value level. Thus, the generated model really adequately describes the data set and allows to estimate the probability of an event occurrence (the person falls into the segment of informal employment).

Based on the results of the obtained model, the author calculated the risks of entering the informal segment of the employed in the Ukrainian labor market. These risks are estimated as a percentage in the range from 0 to 100 . Thus, unmarried men (including divorced and widowed) are at the highest risk of labor relations deformation, gradually with age, the risk 
decreases for both women and men and further increases for the oldest employed (see Table 5).

Table 4

\section{Logistic regression variables}

\begin{tabular}{|c|c|c|c|c|}
\hline & $\begin{array}{c}\text { Equation } \\
\text { coefficient B }\end{array}$ & $\begin{array}{l}\text { Root-mean-square } \\
\text { error (RMSE) }\end{array}$ & $\begin{array}{c}\text { Wald test } \\
\text { Statistics (Wald) }\end{array}$ & $\begin{array}{l}\text { Significance } \\
\text { (Sig.) }\end{array}$ \\
\hline Type of activity (VD) & & & 13,928 & 0,000 \\
\hline Agriculture (VD1) & 0,945 & 0,078 & 14,921 & 0,000 \\
\hline Industry (VD2) & $-0,033$ & 0,065 & 5,264 & 0,031 \\
\hline Services (VD3) & 0,106 & & & 0,000 \\
\hline Age (Vik) & & & 9,242 & 0,027 \\
\hline Age (vik_1); (15-29) & 0,323 & 0,149 & 4,706 & 0,006 \\
\hline Age (vik_2); (30-39) & 0,177 & 0,146 & 6,470 & 0,019 \\
\hline Age (vik_3); (40-49) & $-0,007$ & 0,147 & 7,002 & 0,002 \\
\hline Age (vik_4); (50-59) & $-0,167$ & 0,148 & 5,269 & 0033 \\
\hline Age (vik_5); (60-70) & & 0,144 & 7,784 & 0,004 \\
\hline Education (Osvita) & & & 18,7894 & 0,042 \\
\hline $\begin{array}{l}\text { Professional education } \\
\text { (higher or vocational); } \\
\text { (osvita_1) }\end{array}$ & $-3,954$ & 1,703 & 11,456 & 0,003 \\
\hline $\begin{array}{l}\text { No professional education } \\
\text { (osvita_2) }\end{array}$ & 3,986 & 1,743 & 19,754 & 0,002 \\
\hline Gender (Stat) & 2,680 & 1,396 & 14,832 & 0,0102 \\
\hline Marital status (sim_stan) & 14,836 & 0,825 & 4,965 & 0,032 \\
\hline Constant & $-5,824$ & 1,463 & 5,986 & 0,021 \\
\hline
\end{tabular}

Source: model calculation data.

Table 5

Gender-age distribution of the risk of informal employment, \%

\begin{tabular}{|c|c|c|}
\hline Age group, years old & Women & Men \\
\hline $15-24$ & 25,5 & 36,3 \\
\hline $25-29$ & 18,6 & 28,0 \\
\hline $30-34$ & 16,8 & 24,6 \\
\hline $35-39$ & 17,3 & 23,9 \\
\hline $40-49$ & 18,1 & 25,2 \\
\hline $50-59$ & 19,6 & 24,3 \\
\hline $60-70$ & 27,3 & 26,4 \\
\hline
\end{tabular}

Source: author's own calculations.

The distribution of informal employment among young people is explained by the search for earnings while obtaining education and for persons of the oldest age group - by low rates of replacement of pensions and correspondingly high levels of poverty. Having a family relationship for both men and women contributes to the fact that the employee prefers formal employment relationships. 
The quality of education, professional competences acquired in the field of vocational education significantly increase the likelihood of obtaining employment in the formal segment of labor market. We have assessed the risks of labor flow to the informal segment, with and without vocational education and depending on the scope of work (see Table 6).

Table 6

\begin{tabular}{|l|c|c|c|c|}
\multicolumn{4}{|c}{ Educational-sectoral distribution of the risk of informal employment, \% } \\
\cline { 2 - 5 } & \multicolumn{2}{c|}{ Women } & \multicolumn{2}{c|}{ Men } \\
\cline { 2 - 4 } & $\begin{array}{c}\text { with professional } \\
\text { education }\end{array}$ & $\begin{array}{c}\text { without } \\
\text { education }\end{array}$ & $\begin{array}{c}\text { with professional } \\
\text { education }\end{array}$ & $\begin{array}{c}\text { without } \\
\text { education }\end{array}$ \\
\hline Agriculture, forestry and fisheries & 37,27 & 66,38 & 41,17 & 59,54 \\
\hline Industry & 5,25 & 12,09 & 5,43 & 10,38 \\
\hline Construction & 36,09 & 55,00 & 51,92 & 67,02 \\
\hline $\begin{array}{l}\text { Wholesale and retail trade; repair of motor } \\
\text { vehicles and motorcycles }\end{array}$ & 17,52 & 24,76 & 18,03 & 27,10 \\
\hline $\begin{array}{l}\text { Transport, warehousing, postal and courier } \\
\text { activities }\end{array}$ & 14,11 & 25,44 & 18,22 & 25,30 \\
\hline Temporary accommodation and catering & 21,68 & 34,29 & 22,81 & 33,33 \\
\hline Information and telecommunications & 6,88 & 25,00 & 8,55 & 27,00 \\
\hline Financial and insurance activities & 11,71 & 5,00 & 10,04 & 25,00 \\
\hline Real estate transactions & 12,50 & 22,00 & 7,86 & 20,00 \\
\hline Professional, scientific and technical activities & 3,73 & 4,00 & 3,31 & 3,00 \\
\hline Administrative and support service activities & 10,69 & 29,50 & 9,74 & 15,71 \\
\hline $\begin{array}{l}\text { Public administration and defense; compulsory } \\
\text { social security }\end{array}$ & 3,28 & 19,00 & 4,06 & 10,10 \\
\hline Education & 4,15 & 22,13 & 4,87 & 31,50 \\
\hline Health care and social assistance & 2,91 & 19,47 & 3,52 & 28,15 \\
\hline Arts, sports, entertainment and recreation & 3,76 & 14,35 & 4,11 & 7,67 \\
\hline Other economic activities & 10,13 & 16,00 & 8,78 & 17,25 \\
\hline
\end{tabular}

Source: author's own calculations.

Our calculations prove that the risk of falling into the informal employment segment is much higher for those without vocational training. The "gain" of professional competencies is significantly higher for women employed in agriculture (29.1 pp.), information and telecommunication (18.1 pp.) This is due, first of all, to the fact that in the context of the critical shortage of rural jobs, the only area of employment is the in subsidiary farms and mostly illegal hired employment in common farms. Most likely, men with no education will be informally employed in construction $(67.02 \%$ of $100 \%$ possible), agriculture $(59.5 \%)$, and hotel and restaurant business $(33.3 \%)$, i. e. in those sectors where the share of informal employment is above average. Interestingly, the risk of informality in the field of financial activities for women with vocational education increases (11.7\% compared to 5\% without education), and for men it decreases (10.04\% compared to $25 \%$ without education).

High probability of informal employment in the construction and trade and repair sectors is partly explained by the fact that these sectors account for a significant share of total employment in Ukraine. Moreover, these types of economic activity are characterized by the presence of a large number of micro-enterprises and small enterprises, where the 


\section{Blyzniuk V.V.}

largest volume of informal employment is concentrated, including in the informal sector enterprises.

The assessment of risks of the de-formalization of labor relations as to professional structure proves that with the increase of professional level, the risk decreases in all sectors. Thus, the risk distribution for agriculture is within the limit of $70.8 \%$ for the simplest professions, and $13 \%$ for the higher skilled occupations (1-3 group of the State Classifier of Professions), for trade and hotel and restaurant business this distribution is within the limits of $48.2 \%$ and $5.7 \%$ respectively. The structure of the informally employed and its level in 2018 indicates that informal labor relations are more common among representatives of the simplest professions, trade workers and skilled workers with the tool.

This is also confirmed by the statistics on informal employment. Thus, among the professional groups most represented among the informally employed are workers of the simplest professions - 52.3\% of all informally employed, trade workers - 585.9 thousand $(6.5 \%)$ and skilled workers with the tool - 571.6 thousand persons or $16.1 \%$ informally employed. Analysis of the lower-level occupations allows to assess specific occupations, not just the broad professional groups.

A more detailed analysis of informal employment (by professions) reveals that among the informally employed it is possible to distinguish the top 10 most common occupations among the informally employed. They include the simplest agricultural professions $(41.15 \%$ of all informally employed), and in industry (4.56\%), as well as various kinds of market and store assistants, vendors, drivers, mechanics, and various kinds of construction occupations (see Table 7).

Top 10 professions of the informally employed in Ukraine, \%

Table 7

\begin{tabular}{|c|l|c|}
\cline { 2 - 3 } \multicolumn{1}{c|}{} & \multicolumn{1}{|c|}{ Professions of the informally employed } & Share in total employed \\
\hline 1 & The simplest professions in agriculture & 41,15 \\
\hline 2 & Sellers in stores & 7,65 \\
\hline 3 & Vendors trading in trays and markets & 5,10 \\
\hline & $\begin{array}{l}\text { The simplest professions in the industry (hand works, other than } \\
\text { assembly) }\end{array}$ & 4,56 \\
\hline 5 & Vehicle drivers and vehicle maintenance workers & 3,49 \\
\hline 6 & Plasterers & 2,42 \\
\hline 7 & Builders, structure repairers, and climbers & 2,37 \\
\hline 8 & Painters & 1,91 \\
\hline 9 & Mechanics and assemblers of motor transport vehicles & 1,36 \\
\hline 10 & Hairdressers and makeup artists and cosmetics & 1,32 \\
\hline
\end{tabular}

Source: author's estimate on the microfiles database of household surveys on economic activity.

The demoralization of labor relations is accompanied by risks for the state and society as a whole: the lack of revenues to the budget and social funds, which could be spent on social and economic purposes and on raising standards and quality of life; complicated employment regulation; aggravation of corruption and shadow economy; complicated control over monetary circulation; limited possibility of obtaining complete and reliable 
economic information, which negatively affects macroeconomic forecasting, and the elaboration of national programs of socio-economic development. Besides, owing to low capital intensity, predominance of primitive technologies, and low labor productivity, employment in the informal sector somewhat hinderseconomic modernization and formation of a stable market system.

The effectiveness of a country's macroeconomic development is assessed with a sufficient number of parameters including the labor productivity, which is a largely alternative source of economic growth for the economy as a whole and for individual institutional sectors. There is a tendency of gradual growth of labor productivity For developed countries, which leads to changes in output in various sectors of the economy.

Due to the influence of various factors on the growth of labor productivity and changes in the functioning of Ukraine's economy, it is important to justify the influence of individual factors on the dynamics of this indicator. The growth of aggregate labor productivity depends on the dynamics of labor productivity in each economic activity. Also, one of the significant factors influencing the aggregate productivity is the structure and level of employment, and the narrowing of the capacity of the formal sector of the economy. In other words, the relocation of labor between the formal and informal sectors is a significant factor in aggregate labor productivity.

The intra-industry and relocation components of the impact on labor productivity are of different nature. The first one is related to the accumulation of physical and human capital, intangible assets, and technology development. The second one depends directly on the structural changes in the economy as a whole, and certain economic activities in particular. For example, an increase in household income changes the demand for goods in favor of more expensive ones, which influences accordingly the employment structure in the economy. The informal economy is characterized by a generally low level of capital intensity, technological level and human capital. Companies operating in the informal sector are restricted in access to loans, and as a result, they are characterized by low levels of output labor productivity [31], but entry into this segment of economic activity is freer due to the existing institutional constraints in the formal sector of the economy. La Porte and Schleifer [32] estimate that the median productivity of informal enterprises is about $15 \%$ of the median productivity of formal sector enterprises, and if the self-employment segment is considered, these figures will be even lower. Accordingly, the authors conclude on the significant impact of the labor relocation between informal and formal segments. This emphasizes the importance of estimates of the relocation effect for Ukraine. In Ukraine, effect estimates of the movement of workers between formal and informal sectors by industry were considered [33], which shows that according to the results of this work, the strongest effect of the relocation of workers occurred in the sectors of real estate and agriculture.

In the paper we will assess the impact of the factor of labor flow from formal to informal segments from 2014 to 2018 using methodological adescribed here [34]. The formal segment is presented by companies of the corporate sector, and the output produced by other companies (non-corporate sector) is considered to be produced in the informal sector, which is more in line with the methodological approaches of "productive" 
treatment of informality. According to the calculations during 2014-2018, in Ukraine, $22.9 \%$ of the gross value added of the informal segment of economic activity was created by $21.64 \%$ of informally employed (see Table 8 ).

Table 8

Shares of gross value added and employed in Ukraine's informal sector by economic activity, 2014-2018

\begin{tabular}{|l|c|c|c|c|c|c|}
\hline \multirow{2}{*}{ Economic activities } & \multicolumn{2}{|c|}{ GVA, $\%$} & \multicolumn{2}{c|}{ employed, \% } & \multicolumn{2}{c|}{ change, p. p. } \\
\cline { 2 - 7 } & 2014 & 2018 & 2014 & 2018 & GVA & Employed \\
\hline Agriculture, forestry and fisheries & 49,60 & 43,1 & 68,45 & 62,25 & $-6,5$ & $-6,2$ \\
\hline Mining and quarrying & 0,01 & 0,02 & 2,82 & 0,86 & 0,01 & $-1,96$ \\
\hline Manufacturing & 7,78 & 4,6 & 12,00 & 8,6 & $-3,18$ & $-3,4$ \\
\hline $\begin{array}{l}\text { Supply of electricity, gas, steam and air } \\
\text { conditioning }\end{array}$ & 0,04 & 0,01 & 0,68 & 0,35 & $-0,03$ & $-0,33$ \\
\hline $\begin{array}{l}\text { Water supply; sewerage, waste } \\
\text { management }\end{array}$ & 2,99 & 4,4 & 4,37 & 1,53 & 2,33 & $-2,84$ \\
\hline Construction & 33,88 & 30,8 & 61,03 & 53,12 & $-3,37$ & $-7,91$ \\
\hline $\begin{array}{l}\text { Wholesale and retail trade; repair of motor } \\
\text { vehicles and motorcycles }\end{array}$ & 29,49 & 21,2 & 31,63 & 21,1 & $-9,47$ & $-10,53$ \\
\hline $\begin{array}{l}\text { Transportation, warehousing, postal and } \\
\text { courier activities }\end{array}$ & 11,24 & 14,8 & 16,02 & 13,8 & 3,18 & $-2,22$ \\
\hline Temporary accommodation and catering & 56,73 & 65,8 & 33,99 & 23,11 & 10,03 & $-10,88$ \\
\hline Information and telecommunications & 27,81 & 42,3 & 11,39 & 11,2 & 22,48 & $-0,19$ \\
\hline Financial and insurance activities & 1,67 & 2,7 & 3,33 & 3,4 & 1,03 & 0,07 \\
\hline Real estate transactions & 70,62 & 73,6 & 12,05 & 11,6 & 6,4 & $-0,45$ \\
\hline $\begin{array}{l}\text { Professional, scientific and technical } \\
\text { activities }\end{array}$ & 23,28 & 38,3 & 7,81 & 7,9 & 17,01 & 0,09 \\
\hline $\begin{array}{l}\text { Administrative and support service } \\
\text { activities }\end{array}$ & 20,43 & 26,8 & 15,38 & 8,71 & 10,7 & $-6,67$ \\
\hline Education & 2,33 & 3,5 & 0,54 & 0,32 & 0,44 & $-0,22$ \\
\hline Healthcare and social assistance & 6,58 & 8,7 & 1,36 & 0,76 & 1,92 & $-0,6$ \\
\hline Arts, sports, entertainment and recreation & 9,81 & 17,3 & 10,08 & 13,41 & 7,38 & 3,33 \\
\hline Other services & 87,16 & 86,9 & 36,91 & 7,14 & $-0,28$ & $-29,77$ \\
\hline Total & 22,59 & 22,9 & 25,13 & 21,64 & 0,22 & $-3,49$ \\
\hline
\end{tabular}

Source: calculated and compiled according to the official website of the State Statistics Service of Ukraine.

A big share of the labor input in the informal sector is characteristic for agriculture, construction, trade, hotel and restaurant activities, as well as other public, social and personal services. Dynamic characteristics prove that by the end of the analyzed period, employment in the informal sector of agriculture significantly decreased (by $17.9 \%$ to base period), in manufacturing the decrease amounted to $20.03 \%$, and in wholesalingto $28.6 \%$. There is an increase in the share of gross value added in professional activities (15.02 p. p.), information and telecommunications (14.5 p. p.), catering (9.1 p. p.), and arts, sports and recreation (7.5 p. p.). In the agricultural, construction and wholesale companies, the decrease in GVA in the informal segment was from 3.1 p. p. to 8.3 p. p. 
The estimates of the effect of relocation with the division of each industry into formal/informal segments may have some differences due to the detailing of the distribution of economic activities and, accordingly, the degree of consideration of the factor of the flow of workers from the formal to informal sectors. The growth of aggregate labor productivity depends both on changes in labor productivity within the formal and informal sectors and on the redistribution of labor between these sectors. To evaluate the impact of each of the aforementioned factors of labor productivity, which occur within and between each segment, is possible by decomposing them. This allows revealing the impact of labor relocation in the formal and informal sectors.

As can be seen from the Table 9, the impact of the relocation component on the overall change in labor productivity is stronger in agriculture, construction, wholesale, catering, information and telecommunications, and professional activities.

Table 9

Impact of the relocation component of labor productivity growth in Ukraine, \%

\begin{tabular}{|l|c|c|}
\hline \multirow{2}{*}{ Economic activities } & \multicolumn{2}{c|}{ Change in productivity at the expense of } \\
\cline { 2 - 3 } & intrasector factors & intersector labor relocation \\
\hline Agriculture, forestry and fisheries & 12,156 & 32,589 \\
\hline Mining and quarrying & 7,348 & 0,011 \\
\hline Manufacturing & 16,629 & 3,810 \\
\hline Supply of electricity, gas, steam and air conditioning & 3,365 & 0,006 \\
\hline Water supply; sewerage, waste management & 0,406 & 0,129 \\
\hline Construction & 5,895 & 6,640 \\
\hline $\begin{array}{l}\text { Wholesale and retail trade; repair of motor vehicles } \\
\text { and motorcycles }\end{array}$ & 16,115 & 18,768 \\
\hline $\begin{array}{l}\text { Transportation, warehousing, postal and courier } \\
\text { activities }\end{array}$ & 7,990 & 4,328 \\
\hline Temporary accommodation and catering & 0,450 & 7,906 \\
\hline Information and telecommunications & 1,345 & 5,080 \\
\hline Financial and insurance activities & 0,582 & 0,164 \\
\hline Real estate transactions & 0,104 & 1,805 \\
\hline Professional, scientific and technical activities & 1,305 & 4,339 \\
\hline Administrative and support service activities & 1,420 & 2,446 \\
\hline $\begin{array}{l}\text { Public administration and defense; compulsory social } \\
\text { insurance }\end{array}$ & 9,547 & - \\
\hline Education & 11,301 & 1,741 \\
\hline Health care and social assistance & 6,791 & 2,880 \\
\hline Arts, sports, entertainment and recreation & 0,504 & 0,772 \\
\hline Other services & 0,339 & 8,512 \\
\hline Total activities & 100,485 & 113,812 \\
\hline
\end{tabular}

Source: author's calculations according to the State Statistics Service.

The strongest effect of the flow of workers between the corporate and non-corporate sectors of the industry was manifested in rural economy, trade and construction. For health, education, transport, manufacturing, the impact of the intra-industry component on aggregate labor productivity is more significant than the flow factor between formal and informal 
sectors. The weight of the relocation component in the economy as a whole is higher than the intra-industry impact factors (3.4 p. p.). This allowed us to confirm the thesis that structural shifts in employment are a factor in labor productivity because they change the ratio of high- and low-productivity jobs.

Conclusions. Increasing the productivity of a country's economy depends not only on improvements in technology or in the organization of generation of goods and services, but also on what will happen to workers who will be released as a result of these very improvements. Thus, under otherwise equal conditions, aggregated labor productivity will increase if these workers will either change their economic activity status or will work more productively in other workplaces. However, if they find a less productive sphere for labor efforts, aggregated labor productivity would grow more slowly than in a company, or even decrease [35]. This justifies the need to calculate the redistribution factor and the flow of workers from low to high performing activities. This requires the creation of an institutional environment that would facilitate the expansion and creation of new productive jobs and the elimination of inefficient ones. An institutional environment focused on creating conditions in which the interest in economic activities outside the official segment will decrease would objectively promote economic growth. The relocation will have a positive result with institutional support for creating high-performing jobs relative to new businesses'entries and elimination of old and inefficient jobs. Maintaining a sufficiently high proportion of the informal segment of the economy is related not so much to the rigidity of labor law, but to the poor business climate and the weakness of law enforcement practices as an indicator of "institutional failure of the state" [36]. This proves once again the need to change the format of economic policy, to have institutional reform in order to build trust towards the state and its policy, which will form the basis for the unshadowing of labor relations. International experience proves that, given the institutional problems and failures of the market and the state, tough measures aimed at tightening penalties for shadow activity and informal labor relations are less effective than soft instruments aimed at creating incentives for formal employment and developing internal control in workers and employers [37]. First of all, it requires the implementation of a comprehensive development strategy that will change the model of socio-economic development, improving the institutional and business environment, and will increase the quality of regulation, the effectiveness of anti-corruption activities, the result of which should be the intensive creation of formal jobs in the economy.

\section{References}

1. Libanova, E.M., Balanda, A.L. (1998). The informal sector of the labor market: definitions and methods of assessment. Rynok pratsi ta zainiatist naselennia, 6, 245-246 [in Ukrainian]

2. Kharazishvili, Yu.M., Dmytrenko, N.M. (2010). Methodical approach to assess shadow employment in Ukraine. Ekonomika Ukrainy - Economy of Ukraine, 12, 16-28 [in Ukrainian]

3. Kolot, A.M. (2010). Social and labor sphere: the state of relations, new challenges, development trends. Kyiv: KNEU [in Ukrainian]

4. Kostrytsya, V.I., Burlai, T.V. (2019). Undeclared work as a 'new normality' globally and in Ukraine. Ekon. prognozuvannâ - Economy and forecasting, 1, 7-34. https://doi.org/10.15407/ eip2019.01.007 [in Ukrainian] 
5. Grishnova, O., Dmitruk, S. (2015). Human Capital Under Crisis: Evaluation and Preservation Opportunities Search. Visnyk Kyivskoho natsionalnoho universytetu imeni Tarasa Shevchenka. Ekonomika - Bulletin of Taras Shevchenko National university of Kyiv. Economics, 5 (170), 11-16. https://doi.org/10.17721/1728-2667.2015/170-5/2 [in Ukrainian]

6. Shumska, S., Nezhyvenko, O. (2018). Ukrainian Undeclared Work Survey: First Findings. The Scientific Papers NaUKMA. Economics, 3, 1, 89-95. https://doi.org/10.18523/2519-4739312018150626

7. Tsymbal, O. (2017). Undeclared work in Ukraine: forms of manifestation, scope and measures within the labor inspection system. Kyiv: MBP [in Ukrainian]

8. Williams, C., Round, J., Rodgers, P. (2011). Explaining the Normality of Informal Employment in Ukraine: A Product of Exit or Exclusion? American Journal of Economics and Sociology, 3, 729-755. https://doi.org/10.1111/j.1536-7150.2011.00789.x

9. Barberis, N., Shleifer, A., Vishny, R. (1998). A Model of Investor Sentiment. Journal of Financial Economics, 49 (3), 307-343. https://doi.org/10.1016/S0304-405X(98)00027-0

10. Hart, K. (1973). Informal Income Opportunities and Urban Employment in Ghana. The Journal of Modern African Studies, 11, 1, 61-89. https://doi.org/10.1017/S0022278X00008089

11. Recommendations concerning the statistical definition of informal employment. (2003). Seventeenth International Conference of Labour Statisticians (ICLS) URL: http://ilo.org/public/ english/bureau/stat/download/guidelines/russian/defempl.pdf [in Russian]

12. Harris, J.R., Todaro, M.P. (1970, March). Migration, Unemployment and Development: A two Sector analysis. American Economic Review, 126-142.

13. Saavedra, J., Chong, A. (1999). Structural reform, institutions and earnings: Evidence from the formal and informal sectors in urban Peru. Journal of Development Studies, 35 (4), 95-116. https://doi.org/10.1080/00220389908422582

14. Gerxhani, K. (2004). The Informal Sector in Developed and Less Developed Countries: A Literature Survey. Public Choice, 120, 3 (4), 270-275. https://doi.org/10.1023/ B:PUCH.0000044287.88147.5e

15. Portes, A., Sassen-Koob, S. (1987). Making it Underground: Comparative Material on the Informal Sector in Western Market Economies. The American Journal of Sociology, 93, 1, 30-61. https://doi.org/10.1086/228705

16. Cox, R., Watt, P. (2002). Globalization, polarization and the informal sector: the case of paid domestic workers in London. Area, 34.1, 39-47. https://doi.org/10.1111/1475-4762.00055

17. Edgcomb, E.L., Thetford, T. (2004). The informal economy: making it in rural America. FIELD (Microenterprise Fund for Innovation, Effectiveness, Learning and Dissemination) The Aspen Institute. URL: www.fieldus.org

18. Gimpelson, V.E., Kapelyushnikov, R.I. (Eds.). (2006). Non-standard employment in the Russian economy. Moscow: Izd. Dom GU-VShE [in Russian]

19. Fields, G.S. (1990). Labor Market Modeling and the Urban Informal Sector: Theory and Evidence. In D. Turnham, B. Salomé, A. Schwarz (Eds.), The Informal Sector Revisited. Paris: Development Centre of the Organization for Economic Co-Operation and Development.

20. International Seminar: Employment and Inequality Outcomes. (2009, April 8). Is Informal Normal? Towards More and Better Jobs. Paris: OECD. URL: https://www.oecd.org/brazil/ internationalseminaremploymentandinequalityoutcomes.htm

21. Tawab, G.A. (2017, June 21). Informal is the new normal: Why informal employment is here to stay. Ford Foundation Center for Social Justice. URL: https://www.fordfoundation.org/ideas/equalschange-blog/posts/informal-is-the-new-normal-why-informal-employment-is-here-to-stay/

22. Kapelyushnikov, R.I. (2012). Informal employment in Russia: what do alternative definitions say? Moscow: Izd. dom Vysshaya shkola ekonomiki [in Russian]

23. Blyzniuk, V., Shumska, S. (2018). Macroeconomic and global effects of expanding the informal segment of labor market: the case of Ukraine. In Proceeding of the 18th International Scientific 


\section{Blyzniuk V.V.}

Conference: Globalization And Its Socio-Economic Consequences. University of Zilina, 10th - 11th October 2018. Part I. Economic Impact of Migration (pp. 46-53). Rajecke Teplice, Slovak Republic.

24. Blyzniuk, V. (2017). Informal employment in the labor market: features and characteristics of this segment. In International Conference on Theoretical and Applied Economic Practices "Economic growth in conditions of globalization: sustainable development models", the 12th edition, 12-13 October 2017: Vol. II (pp. 177-185). Chisinau: INCE.

25. Yuryk, Ya., Kuzmenko, G. (2016). Creating a scoring model to assess risk events on the labor market. Ekon. prognozuvannâ - Economy and forecasting, 3, 107-118. https://doi.org/10.15407/ eip2016.03.107 [in Ukrainian]

26. Vodopyanova, A.I., Leonova, L.A. (2015). A study of the nature of informal employment. Finansovaya analitika: problemy i resheniya - Financial analytics: science and experience, 6 (240). URL: http://213.226.126.9/fa/2015/fa06/fa0615-13.pdf [in Russian]

27. Yurik, Y.I., Kuzmenko, G.G. (2017). The Possibilities of Estimating Risk Events During Strategic Management of Human Resources. Demohrafiia ta sotsialna ekonomika - Demography and social economy, 3 (31), 61-75. https://doi.org/10.15407/dse2017.03.061

28. Veredyuk, O.V. (2016). Informal employment: structure and risk determinants in Russia. Vestnik SPbGU - St Petersburg University Journal of Economic Studies, SUJES. https://doi.org/10.21638/11701/ spbu05.2016.402 [in Russian]

29. Patsiorkovskii, V.V., Patsiorkovskaya, V.V. (2005). SPSS for sociologists. Moscow: ISEPN RAN [in Russian]

30. Paul, A. (2016). What's the Best R-Squared for Logistic Regression? URL: https://statisticalhorizons.com/r2logistic

31. Perry, G.E., Arias, O.S., Fajnzylber, P., Maloney, W.F., Mason, A.D., Saavedra-Chanduvi, J. (2007). Informality: Exit and Exclusion. Washington (DC): The World Bank. https://doi.org/10.1596/9780-8213-7092-6

32. La Porta, R., Shleifer, A. (2014). Informality and Development. Journal of Economic Perspectives, 28 (3), 109-126. https://doi.org/10.1257/jep.28.3.109

33. Petrova, I.L., Blyzniuk, V.V. (2018). The Ukrainian labor market: imperatives and opportunities for change. Kyiv: NAS of Ukraine, Institute for Economics and Forecasting, National Academy of Sciences of Ukraine. URL: http://ief.org.ua/docs/mg/306.pdf [in Ukrainian]

34. Voronina, S.V. (2016). The impact of reallocation of the employees working in the informal economy on labor efficiency in the Russian regions. Rosiiskoe predprinimatelstvo, 17, 3, 315-328. https://doi.org/10.18334/rp.17.3.34921 [in Russian]

35. Voskoboynikov, I., Gimpelson, V. (2015). Productivity Growth, Structural Change and Informality: The Case of Russia. Voprosy Ekonomiki, 11, 30-61. https://doi.org/10.32609/0042-8736-201511-30-61

36. Gimpelson, V., Kapeliushnikov, R. (2014). Between Light and Shadow: Informality in the Russian Labour Market. IZA DP No. 8279.

37. Horodnic, I.A. (2016). Cash wage payments in transition economies: consequences of envelope wages. IZA World of Labor. https://doi.org/10.15185/izawol.280

Received on 12.03.20 